\title{
PENGARUH KEPUASAN KERJA TERHADAP KUALITAS LAYANAN DENGAN KOMITMEN ORGANISASIONAL SEBAGAI VARIABEL MEDIASI PADA SOPIR PT. LOMBOK TAKSI
}

\author{
Eko Setia Budi ${ }^{1}$, Surati ${ }^{2}$, Sri Wahyulina ${ }^{3}$ \\ 1Dinas Perhubungan Provinsi NTB, Indonesia. E-mail: memoshiki@gmail.com \\ 2faculty of Economics and Business, Mataram University \\ ${ }^{3}$ Faculty of Economics and Business, Mataram University
}

\begin{tabular}{|c|c|}
\hline ARTICLE INFO & ABSTRACT \\
\hline $\begin{array}{l}\text { Keywords: } \\
\text { work satisfaction, organizational commitment, } \\
\text { service quality. } \\
\text { How to cite: } \\
\text { Setia Budi, E, (2019). Pengaruh Kepuasan } \\
\text { Kerja Terhadap Kualitas Layanan Dengan } \\
\text { Komitmen Organisasional Sebagai Variabel } \\
\text { Mediasi Pada Sopir PT. Lombok Taksi, JMM } \\
\text { UNRAM, 157-168 } \\
\text { DOI: } \\
\text { http://dx.doi.org/10.29303/jmm. } \\
\text { v8i2.439 } \\
\end{array}$ & $\begin{array}{l}\text { The growth of online taxi service recently becomes the } \\
\text { threats for PT Lombok Taksi to still survive against the } \\
\text { competition in the business this research is aimed at analyzing } \\
\text { the significant effect of work satisfaction on the service quality } \\
\text { of drivers of PT Lombok Taksi, at analyzing the significant } \\
\text { effect of work satisfaction on organizational commitment, at } \\
\text { analyzing the significant effect of organizational commitment } \\
\text { on service quality of drivers PT Lombok Taksi. This research is } \\
\text { associative-causal the population is all } 532 \text { drivers of Lombok } \\
\text { Taksi from which 84 samples (rounded to 100) were selected as } \\
\text { respondents by applying the Slovin formula. The samples were } \\
\text { selected through propotional random sampling technique. The } \\
\text { hypothesis test was conducted using path analysis using SPSS } \\
\text { program version 16.00 for windows. } \\
\text { Maraknya taksi online yang menjamur akhir-akhir ini } \\
\text { menjadikan tantangan tersendiri bagi PT. Lombok Taksi untuk } \\
\text { dapat bertahan ditengah persaingan yang semakin kompetitif } \\
\text { saat ini. Penelitian ini bertujuan untuk untuk menganalisis } \\
\text { signifikansi pengaruh dari kepuasan kerja terhadap kualitas } \\
\text { layanan pada sopir Lombok Taksi. Untuk menganalisis } \\
\text { signifikansi pengaruh dari kepuasan kerja terhadap Komitmen } \\
\text { Organisasional pada sopir Lombok Taksi. Untuk menganalisis } \\
\text { signifikansi pengaruh dari Komitmen Organisasional terhadap } \\
\text { Kualitas Layanan pada sopir Lombok Taksi. Jenis penelitian } \\
\text { yang digunakan dalam penelitian ini adalah penelitian } \\
\text { assosiatif kausal. Populasi dalam penelitian ini adalah seluruh } \\
\text { Sopir Lombok Taksi yang berjumlah 532 orang. Penentuan } \\
\text { sampel dengan menggunakan rumus Slovin akan dipilih 84 } \\
\text { orang dibulatkan menjadi } 100 \text { orang sebagai responden. Teknik } \\
\text { pengambilan sampel yang digunakan dalam penelitian ini } \\
\text { adalah proportional random sampling. Dalam penelitian ini, uji } \\
\text { hipotesis menggunakan analisa jalur (path analysis). Analisis } \\
\text { ini dilakukan dengan menggunakan program SPSS 16.00 for } \\
\text { windows. } \\
\quad \text { Hasil penelitian menemukan beberapa hal yaitu }\end{array}$ \\
\hline
\end{tabular}




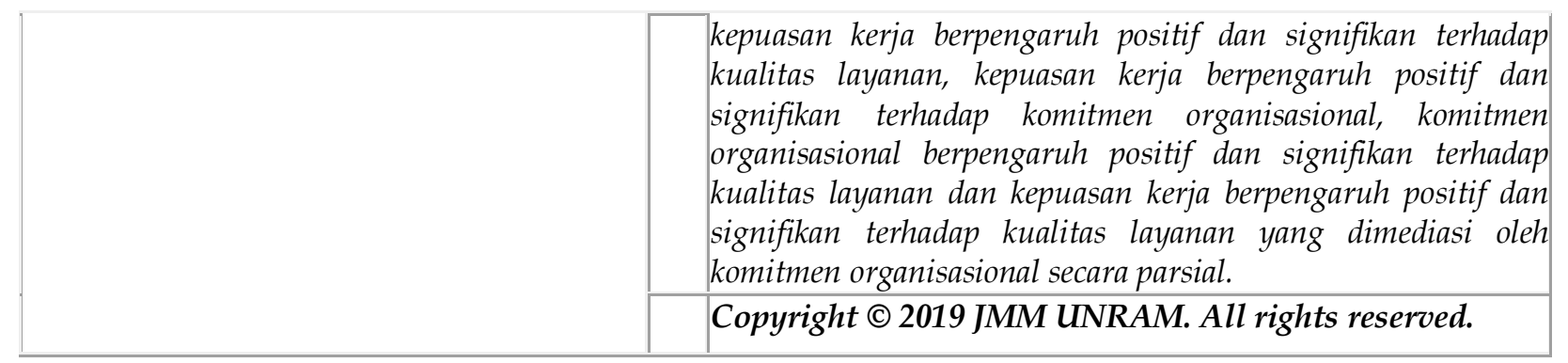

\section{PENDAHULUAN}

Kinerja karyawan merupakan hasil proses yang kompleks, baik berasal dari diri pribadi karyawan (internal factor) maupun upaya strategis dari perusahaan. Setiap perusahaan mengharapkan kinerja terbaik dalam operasinya. Salah satunya perusahaan jasa yang terus dituntut meningkatkan kualitas layanan yang diberikan kepada konsumennya. Apabila perusahaan tidak memiliki kualitas yang baik dalam memberikan pelayanannya kepada konsumen maka mereka tidak dapat bertahan dalam kancah persaingan bisnis yang semakin ketat.

Berdasarkan definisi dari beberapa ahli, dapat disimpulkan bahwa kualitas layanan merupakan bentuk dan sebuah janji atau komitmen dari perusahaan untuk dapat memenuhi segala keinginan dan harapan para pelanggannya, serta terdapat banyak faktor yang mempengaruhi kualitas layanan di dalam suatu perusahaan, salah satunya adalah kepuasan kerja. Kepuasan kerja merupakan sebuah media untuk mengukur atau mengevaluasi seberapa jauh perusahaan dapat memenuhi harapan yang dimiliki karyawan yang berkaitan dengan berbagai aspek dalam pekerjaan dan jabatannya (Kuswadi, 2004:13; Robbins, 2002:147; Simamora, 2006:448).

Kepuasan merupakan sebuah hasil yang dirasakan oleh karyawan, jika karyawan puas dengan pekerjaannya, maka ia akan betah bekerja pada organisasi tersebut, dengan mengerti output yang dihasilkan, maka perlu mengetahui penyebab yang bisa mempengaruhi kepuasan tersebut. Selain kepuasan kerja, komitmen organisasional juga dapat mempengaruhi kualitas layanan yang diberikan oleh seorang karyawan. Komitmen Organisasional menurut Ivancevich dkk (2007:234) adalah perasaan identifikasi, keterlibatan, dan kesetiaan yang diekspresikan oleh karyawan terhadap organisasi. Bukti penelitian menunjukkan bahwa tidak adanya Komitmen Organisasional dapat mengurangi efektivitas organisasi.

\section{TUJUAN PENELITIAN}

Tujuan dari penelitian ini adalah sebagai berikut:

1) Untuk menganalisis signifikansi pengaruh dari kepuasan kerja terhadap kualitas layanan pada sopir Lombok Taksi.

2) Untuk menganalisis signifikansi pengaruh dari kepuasan kerja terhadap Komitmen Organisasional pada sopir Lombok Taksi.

3) Untuk menganalisis signifikansi pengaruh dari Komitmen Organisasional terhadap Kualitas Layanan pada sopir Lombok Taksi. 


\section{KAJIAN KEPUSTAKAAN DAN HIPOTESIS}

\subsection{Definisi Kepuasan Kerja}

Kepuasan kerja didefinisikan menurut Susilo Martoyo (1992:115), pada dasarnya merupakan salah satu aspek psikologis yang mencerminkan perasaaan seseorang terhadap pekerjaannya, ia akan merasa puas dengan adanya kesesuaian antara kemampuan, keterampilan dan harapannya dengan pekerjaan yang ia hadapi. Kepuasan sebenarnya merupakan keadaan yang sifatnya subyektif yang merupakan hasil kesimpulan yang didasarkan pada suatu perbandingan mengenai apa yang diterima karyawan dari pekerjaannya dibandingkan dengan yang diharapkan, diinginkan dan dipikirkannya sebagai hal yang pantas atau berhak atasnya.

Mengenai batasan atau definisi kepuasan kerja menurut penulis belum ada keseragaman. Walaupun demikian sebenarnya tidaklah terdapat perbedaan yang prinsip dari padanya. Menurut Wexley \& Yukl (1997) dalam bukunya As'ad (2004:104) yang disebut kepuasan kerja ialah "is the way an employee feels about his her job". Ini berarti kepuasan kerja sebagai "perasaan sesorang terhadap pekerjaan". Ada yang memberi batasan sebagai "positive emotional state" (Athanasiou, 1973).

Robbins dan Judge (2008:107) mendefinisikan kepuasan kerja sebagai suatu perasaan positif tentang pekerjaan seseorang yang merupakan hasil dari sebuah evaluasi karakteristiknya. Dalam konsep tersebut, pekerjaan seseorang lebih dari sekedar aktivitas mengatur kertas, menulis kode program, menunggu pelanggan, atau mengendarai sebuah truk. Setiap pekerjaan menuntut interaksi dengan rekan kerja dan atasan-atasan, mengikuti peraturan dan kebijaksanaan-kebijaksanaan organisasional, memenuhi standar-standar kinerja, menerima kondisi-kondisi kerja yang kurang ideal, dan lain-lain. Ini berarti bahwa penilaian seorang karyawan tentang seberapa ia merasa puas atau tidak puas dengan pekerjaan merupakan penyajian yang rumit dari sejumlah elemen pekerjaan yang berlainan.

\subsubsection{Faktor-faktor Kepuasan Kerja}

Kepuasan kerja dan ketidakpuasan kerja (job dissatisfaction) itu merupakan dua hal yang berbeda (Herzberg, 1966). Artinya, kepuasan dan ketidak puasan terhadap pekerjaan itu tidak merupakan suatu variabel yang kontinyu. Herzberg (1959) dalam bukunya As'ad (2004:108) membagi situasi yang mempengaruhi sikap seseorang terhadap pekerjaannya menjadi dua kelompok yaitu kelompok satisfiers atau motivator dan kelompok dissatisfiers atau hygiene factors. Kelompok satisfiers (motivator) ialah faktor-faktor atau situasi yang dibuktikannya sebagai sumber kepuasan kerja yang terdiri dari achievement, recognation, work it self, responsibility and advancement. Dikatakannya bahwa hadirnya faktor ini akan menimbulkan kepuasan, tetapi tidak hadirnya faktor ini tidaklah selalu mengakibatkan ketidakpuasan. Selanjutnya kelompok dissatisfiers (hygiene faktors) ialah faktor-faktor yang terbukti menjadi sumber ketidak puasan, yang terdiri dari company policy and administration, supervision technical, salary, interpersonal relations, working condition, job security and status (Wexley dan Yukl, 1977:103). Perbaikan terhadap kondisi atau situasi ini akan mengurangi atau menghilangkan ketidak puasan, tetapi tidak akan menimbulkan kepuasan karena ia bukan sumber kepuasan kerja. Jadi, menurut teori ini, perbaikan salary atau working condition tidak akan menimbulkan kepuasan tetapi hanya mengurangi ketidak puasan.

\subsection{Komitmen Organisasional}

Komitmen Organisasional didefinisikan sebagai kekuatan yang bersifat relatif dari individu dalam mengidentifikasikan keterlibatan dirinya kedalam bagian organisasi, yang 
dicirikan oleh penerimaan nilai dan tujuan organisasi, kesediaan berusaha demi organisasi dan keinginan mempertahankan keanggotaan dalam organisasi (Robbins and Judges, 2008).

Menurut Gibson dkk (2008:315) komitmen terhadap organisasi melibatkan tiga sikap: (1) identifikasi dengan tujuan organisasi, (2) perasaaan keterlibatan dalam tugas-tugas organisasi, dan (3) Perasaaan loyalitas terhadap organisasi. Sehingga dimaknai bahwa Komitmen Organisasional merupakan suatu bentuk identifikasi, loyalitas dan keterlibatan yang diekspresikan oleh karyawan terhadap organisasi. Karyawan yang memiliki komitmen yang baik berarti bahwa karyawan tersebut memiliki loyalitas terhadap organisasi dimana ia berada saat ini dan akan berupaya dengan optimal mencapai tujuan organisasi tempat ia bekerja.

Komitmen Organisasional menurut Ivancevich dkk (2007:234) adalah perasaan identifikasi, keterlibatan, dan kesetiaan yang diekspresikan oleh karyawan terhadap organisasi. Berdasarkan pengertian tersebut dapat diidentifikasi bahwa komitmen terhadap organisasi melibatkan tiga sikap yaitu, rasa identifikasi dengan tujuan organisasi, perasaan terlibat dalam tugas-tugas organisasi, dan perasaan setia terhadap organisasi. Bukti penelitian menunjukkan bahwa tidak adanya Komitmen Organisasional dapat mengurangi efektivitas organisasi.

\subsubsection{Indikator Komitmen Organisasi}

Indikator untuk mengukur komitmen organisasi menurut Porter dan Smith (dalam Steers dan Porter, 1983:442-443) adalah :

1. Kepercayaan yang kuat dan penerimaan terhadap nilai-nilai dan tujuan organisasi.

2. Kesiapan dan kesediaan untuk berusaha dengan sungguh-sungguh atas nama organisasi, dan

3. Keinginan untuk mempertahankan keanggotaan dalam organisasi.

Berdasarkan tiga dimensi dari komitmen organisasi, maka dapat dirumuskan indikator atau pengukur dari masing-masing variabel sebagaimana yang dijelaskan di bawah ini (Meyer, Allen, Smith (1993) dalam Mas'ud, 2004:223).

1) Unsur-unsur pengukur komitmen afektif (affectif commitment) terdiri dari:

(1) Adanya kebahagiaan menghabiskan karir selama bergabung dalam organisasi.

(2) Merasa bahwa persoalan organisasi juga persoalan karyawan itu sendiri.

(3) Mempunyai rasa memiliki yang kuat pada organisasi

(4) Merasa terikat secara emosional terhadap organisasi.

(5) Merasa menjadi bagian keluarga organisasi.

(6) Merasakan bahwa organisasinya sangatlah berarti.

2) Unsur-unsur pengukur komitmen berkelanjut (continuance comimitment) terdiri dari :

(1) Merasa sulit meninggalkan organisasi meskipun menginginkan.

(2) Adanya keterbatasan alternative pekerjaan lain yang tersedia.

(3) Merasa tetap tinggal di dalam organisasi adalah suatu kebutuhan.

(4) Adanya sedikit pilihan untuk dipertimbangkan apabila meninggalkan organisasi.

(5) Merasa sudah terlalu banyak pengorbanan diri yang diberikan kepada organiasai.

(6) Merasa banyak sekali kehidupan seseorang yang akan terganggu, apabila meninggalkan organisasi. 
3) Unsur-unsur pengukur komitmen normatif (normative commitment) terdiri dari :

(1) Adanya kewajiban untuk tetap bersama atasan.

(2) Merasakan tidak tepat meninggalkan organisasi, walaupun organisasi memberikan keuntungan.

(3) Merasa bersalah apabila meninggalkan organisasi.

(4) Loyal pada organisasi.

(5) Adanya suatu tanggung jawab yang paling tinggi terhadap orang-orang yang berada di dalam organisasi.

(6) Merasa berhutang budi pada organisasi.

\subsection{Kualitas Layanan}

Kualitas pada dasarnya ditentukan oleh kesesuaiannya dengan spesifikasi yang ditawarkan, spesifikasi pada perusahaan jasa berkaitan dengan pengiriman barang tepat waktu atau kecepatan dalam memberikan tanggapan terhadap keluhan pelanggan (Wibowo, 2012). Menurut Ariani (2003), kualitas dapat dicapai apabila delapan elemen telah terpenuhi, yaitu :

a) Fokus pada pelanggan dengan memberikan kepuasan kepada pelanggan sesuai dengan harapan.

b) Komitmen jangka panjang, agar seluruh karyawan mau melaksanakan hal yang sama dengan terlibat secara penuh dalam proses yang ada.

c) Kepemimpinan dan dukungan manajemen puncak, dengan memberikan dukungan tenaga, pikiran, perencanaan strategik, gaya serta perbaikan secara berkesinambungan.

d) Pemberdayaan seluruh personil dan kerja tim dengan mendorong partisipasi seluruh karyawan untuk mencapai sasaran kualitas, termasuk perbaikan dan penyelesaian masalah.

e) Komunikasi efektif dengan mengadakan hubungan komunikasi baik secara formal maupun informal dan komunikasi vertikal maupun horizontal.

\subsubsection{Indikator Kualitas Layanan}

Dalam perspektif sumber daya manusia, kualitas layanan tidak akan hadir tanpa adanya kualitas layanan yang diberikan oleh sumber daya manusia organisasi itu sendiri. Untuk mengukur kualitas layanan dalam perspektif sumber daya manusia tersebut Martin (1991) indikator pengukuran kualitas layanan dalam perspektif sumber daya manusia terdiri dari (1) berhasil dalam pelayanan, (2) Memiliki potensi untuk membangun hubungan dengan orang lain, (3) Berkaitan dengan standar operasional prosedur yang telah ditetapkan perusahaan:

1) Unsur-unsur pengukuran berhasil dalam pelayanan:

a. Merupakan orang yang memiliki sikap yang positif terhadap pekerjaan

b. Secara tulus senang bekerja dengan dan untuk orang lain

c. Mendahulukan memenuhi keinginan orang lain dibandingkan diri sendiri

d. Fleksibel dan menyukai pengalaman baru

2) Unsur-unsur Pengukuran potensi membangun hubungan dengan orang lain:
a. Senang bertemu dengan orang lain
b. Senang melayani orang lain
c. Tidak keberatan meminta maaf untuk kesalahan walaupun bukan kesalahan
d. Memiliki kemampuan berkomunikasi secara lisan dengan orang lain
e. Memiliki kemampuan mengingat nama dan wajah orang lain 


\subsection{Hipotesis}

Dalam penelitian ini terdapat hubungan-hubungan yang menjelaskan keterkaitan antara masing-masing variabel :

\subsubsection{Pengaruh Kepuasan Kerja Terhadap Kualitas Layanan}

Suwatno dan Priansa (2011) menyatakan bahwa bagi karyawan kepuasan kerja akan menimbulkan perasaan menyenangkan dalam bekerja, sedangkan bagi perusahaan kepuasan kerja bermanfaat dalam usaha meningkatkan produksi, perbaikan sikap dan tingkah laku karyawan dalam bekerja. Pada industri jasa, kepuasan kerja menjadi hal yang diperhatikan oleh manajemen perusahaan karena berdampak kepada kualitas pelayanan yang diberikan, hal ini terjadi karena perusahaan jasa berfokus kepada penyampaian kualitas pelayanan dengan membangun loyalitas karyawan dan konsumen melalui kepuasan kerja (Munhurrun et al., 2010). Karyawan akan memberikan layanan yang lebih baik apabila mereka merasa puas (Schmit dan Allscheid, 1995).

Beberapa peneliti terdahulu yaitu Puspitawati dan Riana (2014), Irene, Wijaya, dan Hariyanto (2015), Puspitawati (2013), Berliyanti dan Imelda (2008) telah menemukan bahwa Kepuasan Kerja berpengaruh signifikan terhadap Kualitas Layanan.

Berdasarkan hasil penelitian di atas maka hipotesis yang diajukan adalah

H1 : Diduga kepuasan kerja berpengaruh signifikan terhadap Kualitas Layanan pada sopir Lombok Taksi.

\subsubsection{Pengaruh Kepuasan Kerja terhadap Komitmen Organisasional}

Rivai (2002:249) menyatakan bahwa "Kepuasan kerja merupakan penilaian dari pekerja tentang seberapa jauh pekerjaannya secara keseluruhan memuaskan kebutuhnnya. Kepuasan kerja juga adalah sikap umum yang merupakan hasil dari beberapa sikap khusus terhadap faktor-faktor pekerjaan, penyesuaian diri, dan hubungan sosial di luar kerja.

Komitmen organisasional dapat dibentuk oleh kepuasan kerja diperkuat oleh pendapat Robbins dan Judge (2008:111) bahwa "konsekwensi ketika karyawan menyukai pekerjaan mereka adalah karyawan tersebut memiliki kesetiaan (loyality) yang tinggi terhadap organisasi". Hasil penelitian yang dilakukan oleh Purna (2013) Puspitawati dan Riana (2014), serta Puspitawati (2013) menemukan bahwa kepuasan yang dirasakan seseorang anggota dalam melaksanakan tugas dan tanggung jawabnya tidak bisa dikesampingkan karena dapat mempengaruhi komitmen. Hal ini disebabkan oleh sikap positif yang dirasakannya dalam bekerja sehingga akan membentuk perilaku loyal terhadap pekerjaan dan organisasinya.

Berdasarkan hasil penelitian di atas maka hipotesis yang diajukan adalah :

H2: Diduga kepuasan kerja berpengaruh signifikan terhadap Komitmen Organisasional pada sopir Lombok Taksi.

\subsubsection{Pengaruh Komitmen Terhadap Kualitas Layanan}

Komitmen Organisasional menurut Ivancevich dkk (2007:234) adalah perasaan identifikasi, keterlibatan, dan kesetiaan yang diekspresikan oleh karyawan terhadap organisasi. Komitmen organisasional dapat mempengaruhi kualitas layanan yang diberikan oleh seorang karyawan di dalam perusahaan tempat dia bekerja. Menurut Sopiah (2008) Karyawan yang berkomitmen tinggi akan mempengaruhi kinerja perusahaan. Artinya karyawan yang memiliki komitmen akan bekerja sepenuh hati, tulus dan ikhlas melayani konsumen tanpa harus dipaksa terlebih dahulu. 
Beberapa peneliti terdahulu yaitu Puspitawati dan Riana (2014), Irene, Wijaya, dan Hariyanto (2015), dan Puspitawati (2013) menemukan bahwa Komitmen Organisasional berpengaruh signifikan terhadap dan Kualitas Layanan.

Berdasarkan hasil penelitian di atas maka hipotesis yang diajukan adalah

\section{H3 : Diduga Komitmen Organisasional berpengaruh signifikan terhadap Kualitas Layanan pada Lombok Taksi.}

\section{METODE PENELITIAN}

Jenis penelitian yang digunakan dalam penelitian ini adalah penelitian assosiatif kausal. Populasi dalam penelitian ini adalah seluruh Sopir Lombok Taksi yang berjumlah 532 orang. Penentuan sampel dengan menggunakan rumus Slovin akan dipilih 84 orang dan dibulatkan menjadi 100 orang sebagai responden. Teknik pengambilan sampel yang digunakan dalam penelitian ini adalah simple random sampling. Jenis data dalam hal ini adalah data kualitatif yang dirubah menjadi data kuantitatif yaitu berupa skor atau angka pada pertanyaan penelitian. Dalam penelitian ini ada dua sumber data yang diperoleh yaitu data primer dan sekunder. Teknik pengumpulan data dalam penelitian ini adalah teknik angket dan dokumentasi. Alat pengumpulan data yang digunakan dalam penelitian ini adalah kuesioner, yang berisi tentang pernyataan yang terkait dengan permasalahan yang diteliti. Varibel-variabel yang akan dianalisis dalam penelitian ini adalah kualitas layanan $(\mathrm{Y})$ sebagai variabel terikat (dependen variabel), kepuasan kerja $(\mathrm{X})$ sebagai variabel bebas (independen variabel) dan komitmen organisasional $(Z)$ sebagai variable mediasi. Dalam penelitian ini, uji hipotesis menggunakan analisa jalur (path analysis). Analisis ini dilakukan dengan menggunakan program SPSS 16.00 for windows.

\section{HASIL DAN PEMBAHASAN}

\subsection{Uji Hipotesis dan Pembahasan}

Dalam penelitian ini, uji hipotesis menggunakan analisa jalur (path analysis). Analisa jalur digunakan untuk menganalisis pola hubungan antar variabel dengan tujuan untuk mengetahui pengaruh langsung dan tidak langsung dari seperangkat variabel bebas terhadap variabel terikat. Analisis ini dilakukan dengan menggunakan program SPSS 16.00 for windows.

\subsubsection{Pengaruh Kepuasan Kerja Terhadap Kualitas Layanan}

Tabel 5.1 Hasil Regresi Sub-Struktur 1

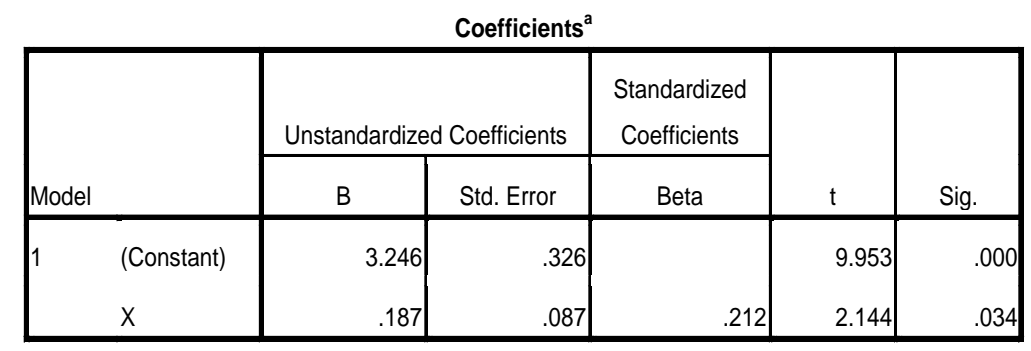

a. Dependent Variable: $Y$

Persamaan struktur :

$\mathrm{Y}=0,212 \mathrm{X}$ 
Terlihat bahwa pada tabel coefficients nilai t-hitung 2,144 dan pada kolom Sig (signifikan) pada tabel diperoleh nilai 0,034 < 0,05 maka Ho ditolak yang artinya variabel kepuasan kerja berpengaruh signifikan terhadap kualitas layanan dengan nilai koefisien jalur sebesar 0,212.

Pengaruh antara Kepuasan Kerja $(X)$ tehadap kualitas layanan $(\mathrm{Y})$ mempunyai nilai koefisien jalur (beta) sebesar 0,212 dengan nilai signifikansi sebesar 0,034 lebih kecil dari nilai probabilitas yang distandarkan sebesar 0,05. Hasil ini menunjukkan bahwa kepuasan kerja berpengaruh signifikan terhadap kualitas layanan dimana hasil ini sesuai dengan hipotesis yang menyatakan bahwa kepuasan kerja berpengaruh signifikan terhadap kualitas layanan.

Menurut Erlan (2017) ketika karyawan merasakan puas terhadap pekerjaannya maka akan memberikan dampak kepada perasaan senang dan bahagia terhadap pekerjaan yang mereka jalani saat ini. Hal ini pun akan sangat bermanfaat bagi jalannya organisasi atau perusahaan dalam meningkatkan pendapatan perusahaan, perbaikan atas sikap dan perilaku karyawan dalam bekerja. Pada industri jasa, kepuasan kerja menjadi hal yang akan sangat diperhatikan oleh manajemen perusahaan karena akan memiliki dampak pada kualitas layanan yang akan mereka berikan. Hal ini terjadi karena perusahaan jasa berfokus pada penyampaian kualitas pelayanan dengan membangun kepuasan kerja akan karyawan itu sendiri terlebih dahulu (Munhurrun et al, 2010). Hal ini sesuai dengan pernyataan yang dikemukakan oleh Schmit dan Allscheid (1995) dimana karyawan akan memberikan layanan yang terbaik ketika mereka merasa puas.

Pada dasarnya kepuasan kerja merupakan hal yang bersifat individual karena setiap individu akan memiliki tingkat kepuasan yang berbeda-beda sesuai dengan nilai-nilai yang berlaku dalam diri setiap individu. Semakin banyak aspek dalam pekerjaan yang sesuai dengan keinginan individu, maka semakin tinggi tingkat kepuasan yang dirasakan. Menurut teori, kepuasan kerja adalah keadaan emosi yang senang atau emosi positif yang berasal dari penilaian pekerjaan atau pengalaman kerja seseorang. Kepuasan kerja dapat dimaknai sebagai hasil dari persepsi karyawan mengenai seberapa baik pekerjaan mereka memberikan hal positif bagi diri mereka sendiri (Luthans, 2006:243).

Karyawan yang merasa puas akan pekerjaannya akan berpengaruh terhadap produktivitas kerja dari karyawan (Steers dan Porter, 1983). Hal ini dikarenakan karyawan yang puas akan dengan senang hati melakukan pekerjaannya tanpa ada keterpaksaan, berbeda dengan karyawan yang tidak puas maka karyawan tersebut akan merasa terpaksa dalam melakukan pekerjaannya. Tentunya, ketika karyawan tersebut merasa terpaksa dalam bekerja maka hasil kerjanyapun akan tidak maksimal dan hal ini akan berdampak terhadap kualitas pekerjaan yang akan dihasilkannya. Penelitian ini sejalan dengan beberapa penelitian terdahulu yang pernah dilakukan oleh Berliyanti dan Imelda (2008), Puspitawati dan Riana (2014) serta Irene et al (2015) yang menemukan bahwa kepuasan kerja memiliki pengaruh yang signifikan terhadap kualitas layanan dengan tanda positif. 


\subsubsection{Pengaruh Kepuasan Kerja terhadap Komitmen Organisasional}

Tabel 5.2 Hasil Regresi Sub-Struktur

\begin{tabular}{|c|c|c|c|c|c|c|}
\hline \multicolumn{7}{|c|}{ Coefficients $^{a}$} \\
\hline \multirow{2}{*}{\multicolumn{2}{|c|}{ Model }} & \multicolumn{2}{|c|}{ Unstandardized Coefficients } & $\begin{array}{l}\text { Standardized } \\
\text { Coefficients }\end{array}$ & \multirow[b]{2}{*}{$\mathrm{t}$} & \multirow[b]{2}{*}{ Sig. } \\
\hline & & B & Std. Error & Beta & & \\
\hline 1 & (Constant) & 3.817 & .606 & & 6.297 & .000 \\
\hline & $x$ & 251 & 163 & 332 & 2.316 & .003 \\
\hline
\end{tabular}

a. Dependent Variable: $z$

Persamaan struktur :

$\mathrm{Z}=0,332 \mathrm{X}$

Terlihat bahwa pada tabel coefficients nilai t-hitung 2,316 dan pada kolom Sig (signifikan) pada tabel diperoleh nilai 0,003 $<0,05$ maka Ho ditolak yang artinya variabel kepuasan kerja berpengaruh signifikan terhadap komitmen organisasional dengan nilai koefisien jalur sebesar 0,332.

Pengaruh antara Kepuasan Kerja $(X)$ tehadap komitmen organisasional (Z) mempunyai nilai koefisien jalur (beta) sebesar 0,332 dengan nilai signifikansi sebesar 0,003 lebih kecil dari nilai probabilitas yang distandarkan sebesar 0,05. Hasil ini menunjukkan bahwa kepuasan kerja berpengaruh signifikan terhadap komitmen organisasional dimana hasil ini sesuai dengan hipotesis yang menyatakan bahwa kepuasan kerja berpengaruh signifikan terhadap komitmen organisasional.

\subsubsection{Pengaruh Komitmen Terhadap Kualitas Layanan}

Tabel 5.3 Hasil Regresi Sub-Struktur 3

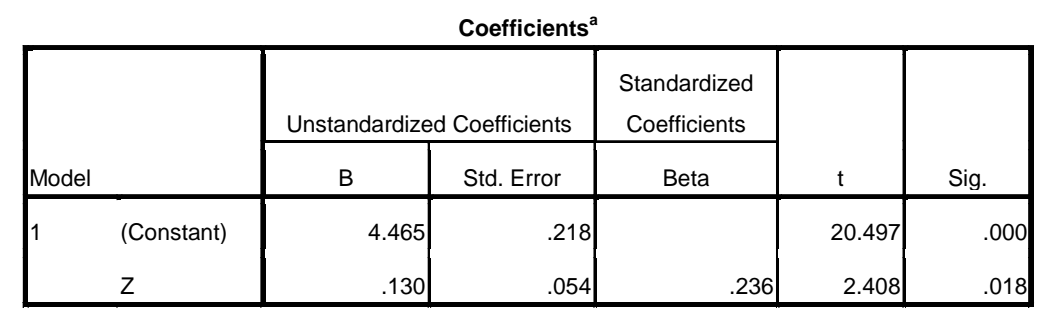

a. Dependent Variable: $Y$

Persamaan struktur :

$\mathrm{Y}=0,236 Z$

Terlihat bahwa pada tabel coefficients nilai t-hitung 2,408 dan pada kolom Sig (signifikan) pada tabel diperoleh nilai 0,018 < 0,05 maka Ho ditolak yang artinya variabel komitmen organisasional berpengaruh signifikan terhadap kualitas layanan dengan nilai koefisien jalur sebesar 0,236.

Pengaruh antara komitmen organisasional $(\mathrm{Z})$ tehadap kualitas layanan $(\mathrm{Y})$ mempunyai nilai koefisien jalur (beta) sebesar 0,236 dengan nilai signifikansi sebesar 0,018 lebih kecil dari nilai probabilitas yang distandarkan sebesar 0,05. Hasil ini menunjukkan bahwa komitmen organisasional berpengaruh signifikan terhadap kualitas layanan dimana hasil ini sesuai dengan hipotesis yang menyatakan bahwa komitmen organisasional berpengaruh signifikan terhadap kualitas layanan. Hal ini memberikan gambaran bahwa 
semakin tinggi rasa komitmen terhadap organisasi sopir Lombok Taksi maka akan meningkatkan kualitas layanan dari para sopir Lombok Taksi.

Menurut Ivancevich et al (2007:234) komitmen organisasional merupakan perasaan identifikasi, keterlibatan, dan kesetiaan yang diekspresikan oleh karyawan terhadap organisasi. Identifikasi karyawan terhadap organisasi melahiran keyakinan dan penerimaan karyawan yang kuat terhadap nilai-nilai dan tujuan organisasi serta rasa bangga menjadi bagian dari organisasi, sebagai dasar dari komitmen karyawan pada organisasi. Identifikasi karyawan dapat dilihat melalui sikap menyetujui kebijakan organisasi, kesamaan antara nilai pribadi dengan nilai-nilai organisasi dan rasa bangga menjadi bagian dari organisasi.

Hal ini merupakan dasar kuat bagi karyawan untuk terlibat dan berkontribusi secara penuh bagi kemajuan perusahaan. Karyawan yang memiliki kesetiaan yang tinggi pada organisasi maka akan mampu menerima tugas dan tanggung jawab secara ikhlas dan lapang dada tanpa ada beban. Hal ini akan berdampak pada kualitas layanan yang akan diberikan oleh sopir Lombok taksi. Menurut Sopiah (2008) karyawan yang berkomitmen tinggi akan mempengaruhi kualitas layanan dari karyawan tersebut. Artinya karyawan akan bekerja sepenuh hati, tulus dan ikhlas melayani konsumen tanpa harus dipaksa terlebih dahulu. Menurut Lewis dan Booms dalam Tjiptono (2012) kualitas layanan merupakan ukuran seberapa baik tingkat layanan yang dapat diberikan sesuai dengan harapan pelanggan. Tingkat layanan yang baik hanya akan dapat diberikan oleh karyawan yang telah merasa memiliki organisasi dan bangga terhadap organisasi dimana tempat mereka bernaung.

\subsubsection{Pengaruh Kepuasan Kerja Terhadap Kualitas Layanan dengan Mediasi Komitmen Organisasional}

Dalam analisa jalur, disamping melihat pengaruh langsung antara variabel independen terhadap variabel dependen, dilihat juga pengaruh tidak langsung antara keduanya.Dalam penelitian ini, terdapat pengaruh tidak langsung antara variabel kepuasan kerja terhadap Kualitas Layanan melalui mediasi Komitmen Organisasional. Dari hasil analisa tersebut, maka untuk menghitung pengaruh tidak langsung tersebut adalah sebagai berikut :

- Kepuasan kerja terhadap kualitas layanan melalui komitmen organisasional

$$
0,332 \times 0,236=0,0783
$$

Dari perhitungan tersebut, memberikan arti bahwa terdapat pengaruh yang tidak langsung antara variabel kepuasan kerja terhadap kualitas layanan yang melalui komitmen organisasional yang memiliki nilai koefisien jalur sebesar 0,0783. Perbandingan pengaruh tidak langsung Kepuasan Kerja terhadap Kualitas Layanan melalui Komitmen Organisasional dengan pengaruh langsung Kepuasan Kerja terhadap Kualitas Layanan diperoleh hasil 0,0783 $<0,212$ sehingga bisa dinyatakan bahwa komitmen organisasional dapat berfungsi sebagai variabel partial intervening dalam pengaruh kepuasan kerja terhadap kualitas layanan pada sopir Lombok Taksi.

\section{KESIMPULAN}

Berdasarkan hasil analisis menggunakan analisa jalur (path analysis) dengan responden sebanyak 100 sopir Lombok Taksi mengenai pengaruh kepuasan kerja terhadap kualitas layanan dengan komitmen organisasional sebagai mediasi, kepuasan kerja berpengaruh positif dan signifikan terhadap kualitas layanan. Hal ini menunjukkan bahwa sopir Lombok Taksi telah merasakan kepuasan dalam bekerja sehingga mampu 
meningkatkan kualitas layanan. Kepuasan kerja berpengaruh positif dan signifikan terhadap komitmen organisasional. Hal ini menunjukkan bahwa sopir Lombok Taksi telah merasakan kepuasan dalam bekerja sehingga meningkatkan komitmen kepada perusahaan. Komitmen organisasional berpengaruh positif dan signifikan terhadap kualitas layanan. Hal ini menunjukkan bahwa dengan komitmen terhadap organisasi yang dimiliki oleh sopir Lombok taksi maka akan meningkatkan kualitas layanan.

\section{DAFTAR PUSTAKA}

As'ad, Moh., (2004), Psikologi Industri, Yogyakarta, Liberty

Adhipura, Made Wahyu (2015), Pengaruh Kepuasan Kerja dan Komitmen Organisasional Terhadap Kualitas Layanan Hotel, Business Management Journal Vol. 11 No. 2

Berliyanti, D. O., dan Imelda, M., (2008), Pengaruh Kepuasan Kerja, Komitmen Organisasi Terhadap Kualitas Jasa Karyawan Call Center Bank X, Jurnal Penelitian, Media Riset Bisnis \& Manjemen Vol.8. No.2, Agustus 2008, pp.193-212.

Erlan. (2017), Pengaruh Kepuasan Kerja dan Kepemimpinan Terhadap komitmen Organisasional dan Kualitas Layanan pada Perum Damri Cabang Mataram, Jurnal Magister Manajemen Universitas Mataram, Maret 2017

Gibson, J. L., Ivancevich, J. M., dan Donnelly, J. H., (2008), Organisasi, Perilaku, Struktur, dan Proses, Jakarta : Binapura Aksara Publisher.

Halim, Ivan Adrian, (2015), Pengaruh Kepuasan Kerja dan Dispilin Kerja pada Kualitas Layanan Sopir di PT Usaha Jaya Gresik, AGORA Vol. 3, No. 2

Haris, Henry. (2017), Pengaruh Kepuasan Kerja dan Komitmen Organisasional Terhadap Kualitas Layanan di PT. Asuransi Jasindo (Persero) Kantor Cabang Korporasi dan Ritel Bandung. Jurnal Ekonomi Manajemen Sumber Daya Vol. 19, No. 2, Desember 2017

Irene, Y. J., Wijaya E. K., dan Hariyanto A., (2015), Pengaruh Kepuasan Kerja Terhadap Kualitas Layanan Melalui Kinerja Karyawan Fave Hotel Mex Surabaya, Artikel Penelitian Manajemen Perhotelan, Universitas Kristen Petra, Surabaya, Indonesia.

Ivancevich, J. M., Robert, K., Michel T. M., (2007), Perilaku dan Manajemen Organisasi, Jilid 1, Jakarta : PT. Gelora Aksara Pratama.

Kotler, Philip dan Gary Amstrong. (1992), Dasar-Dasar Pemasaran I. Jakarta: Intermedia Kuncoro, Shelvye (2017), Pengaruh Kepuasan Kerja dan Komitmen Organisasional Terhadap Kualitas Pelayanan Karyawan Administrasi di Surabaya, repository.wima.ac.id/9905

Luthans, Fred. (2006), Perilaku Organisasi. Yogyakarta: Gadjah Mada University Press. Martin, William B. (1991), Pelayanan Pelanggan yang Bermutu. Jakarta: Binarupa Aksara Martoyo, Susilo, (2000), Manajemen Sumber Daya Manusia. Yogyakarta : BPFE

Marihot Tua Efendi Hariadja, (2002), Manajemen Sumber Daya Manusia. PT. Bumi Aksara, Jakarta

Munhurrun, P.T., Naido, P., \& Bhiwajee, S.D.L. (2010), Measuring service quality: Perception of employees. Journal of Business Research, 4(1), 47-58

Muhidin, Sambas Ali dan Maman Abdurahman. (2011), Analisa Korelasi, Regresi dan Jalur dalam Penelitian. Bandung: CV Pustaka Setia

Nawawi, H., (2000), Manajemen Sumber Daya Manusia Untuk Bisnis Yang Kompetitif. Yogyakarta: Gadjah Mada University Press.

Puspitawati, N. M, dan Dwi, Riana, I. G., (2014), Pengaruh Kepuasan Kerja Terhadap Komitmen Organisasional Dan Kualitas Layanan Hotel Bali Hyatt Sanur, Jurnal Manajemen Strategi Bisnis dan Kewirausahaan Vol.8 No.1, Februari 2014. 
Purna, I Nyoman, (2013), Kepuasan Kerja dan Komitmen Organisasional: Pengaruhnya Terhadap Intensi Keluar. E-Jurnal Ekonomi dan Bisnis Universitas Udayana

Russel, Roberta S. and Taylor Bernard W. (2000), Operation Management. New Jersey: Prentice Hall

Robin Efendi Hariandja, (2003), Manajemen Sumber Daya Manusia. Jakarta. PT Salemba Embun.

Robbins, Stephen P. Dan Timothy A. Judge. (2008), Perilaku Organisasi Edisi ke-12. Jakarta: Salemba Empat

Schmit, M.J., dan Allscheid, S.P. 1995. Employee Attitudes and Customer Satisfaction: Making Theoretical and Empirical Connections". Personnel Psychology, 48(3): 521536

Silalahi, Ulber. (2009), Metode Penelitian Sosial. Bandung: Refika Aditama

Sopiah. (2008), Perilaku Organisasi. Yogyakarta: Andi Offset

Steers R. M. \& Porter L.W. (1987), Motivation and Leadership at Work. New York: McGraw Hill

Suwatno \& Priansa, D. (2011), Manajemen SDM dalam Organisasi Publik dan Bisnis. Bandung: Alfabeta

Steers R. M. \& Porter L.W. (1983), Motivation and Work Behavior. New York: McGraw Hill Book Co

Simamora, Henry, (2006), Manajemen Sumber Daya Manusia. Cetakan Ketiga. Yogyakarta. YPPKN.

Taurisa, C.M dan Ratwati, I (2012), Analisis pengaruh budaya organisasi dan kepuasan kerja terhadap komitmen organisasional dalam meningkatkan kinerja karyawan pada ( PT. Sido Muncul Kaligawe Semarang). Jurnal JBE, September 2012. H.170-187.

Tjiptono, Fandy, (2006), Manajemen Jasa. Edisi Pertama. Yogyakarta: Andi Offset

Winardi, (2004), Manajemen Perilaku Organisasi, Kencana, Jakarta

Wibowo, (2010), Manajemen Kinerja - Edisi Ketiga, Jakarta : PT. Raja Grafindo Persada.

Wuryandradi, Dedi (2014), Pengaruh Kepuasan Kerja, Motivasi dan Budaya Organisasi Terhadap Kualitas Pelayanan PT. Solo Central Taxi Tahun 2011, Jurnal Riset Manajemen Vol. 1, No. 1, Mei 2014, 52-63 